\title{
CANAGARAJAH, RAJAGOPALAN E JORDÃO
}

Gisele Werneck DIVARDIN

O autor A. Suresh Canagarajah é natural de Jaffna, Sri Lanka, onde ensinou inglês e literatura por muitos anos. Tem larga formação lingüística adquirida nos bancos de universidades americanas com pesquisas publicadas em revistas proeminentes da área. Em seu artigo, ele leva o leitor a refletir sobre algumas diferenças conceituais extremas entre a retórica do imperialismo lingüístico e do hibridismo lingüístico para discutir algumas das suas implicações para a prática do professor de EFL nos dias atuais.

Para tal, Canagarajah, oportunamente, critica a opinião emitida pelo lingüista Rajagopalan sobre o papel do professor frente a inevitável relação de poder lingüístico existente entre comunidades lingüísticas diferentes. Rajagopalan, cujo objetivo inicial em seu artigo era o de libertar o professor, mais precisamente o de língua inglesa, de qualquer vestígio de culpa por estar, supostamente, divulgando a retórica do LI (Linguistic Imperialism) ao destacar o status da língua inglesa como língua global, acaba, na opinião de Canagarajah, destituindo o professor do seu importante papel social de agente crítico no exercício de sua profissão. O poder público, na sua visão, tem a total responsabilidade de gerenciar eventuais problemas ocasionados por essa luta pelo poder lingüístico.

Articulando um conjunto de idéias que ora se valem dos princípios apregoados pelo LI (Linguistic Imperialism) e ora pelos do LH (Linguistic Hybridity), Canagarajah, ao contrário do que se espera, não toma partido a favor de nenhuma ideologia. Ele, por sua vez, reconhece o valor que o embate entre elas proporciona na medida em que expande nossa consciência no que diz respeito às complexidades envolvidas nessa negociação pelo poder.

Em posse desse conhecimento, o professor, de acordo com Canagarajah, diferentemente da idéia apresentada por Rajagopalan, deve exercer seu papel não somente para ensinar os mecanismos da língua, mas, acima de tudo, para transformar o espaço da sala de aula numa arena. Lá, professor e aluno, democraticamente, discutirão e negociarão as relações de poder que subjazem as escolhas lingüísticas. Para tal, o professor, no exercício da sua profissão, deve, também, usar a língua como ponto de partida para 
promover discussões que tragam à luz as ideologias e crenças que se apresentam por trás dela, tanto da vernácula como da língua inglesa, em suas diferentes manifestações. O engajamento de professores e alunos em tais discussões, certamente, sensibilizará o aprendiz para essas questões que o transportarão de uma concepção de língua como um código físico para transmitir e receber mensagens para uma concepção de língua como discurso, questão essa discutida por Jordão e retomada logo a seguir. Munido dessa nova visão, na perspectiva de Jordão, espera-se que o aluno, visto como agente social transformador, revele, entenda, questione, discuta, filtre, avalie e modifique os diferentes discursos, locais e estrangeiros, que o cercam para defender e servir seus interesses bem como o da comunidade na qual ele está inserido.

Tais considerações tornam a leitura do texto por profissionais envolvidos com o ensino de língua estrangeira de suma importância.

O artigo de Jordão, por sua vez, assim como o de Canagarajah, trata da concepção de língua como discurso e discute suas implicações na educação.

A autora, de forma clara e didática, contrariando a idéia de que um texto, para ser verdadeiramente científico, deve partir do pressuposto de que todos os seus leitores já possuem profundo entendimento dos conceitos ali contidos, faz questão de discorrer sobre eles ao mesmo tempo em que os utiliza para expor suas idéias. Alguns desses conceitos são: discurso, letramento crítico, cidadania, transculturalidade.

De forma mais abrangente e detalhada que Canagarajah, Jordão enfatiza que a língua, como discurso, é um espaço para a construção de sentidos e que a maneira como entendemos o mundo influencia nossas concepções educacionais e nossa idéia do papel das línguas estrangeiras na formação das pessoas.

Muito oportuno para o leitor, também, sua preocupação de diferenciar o sentido da noção de ser crítico na perspectiva do letramento crítico e daquele usado pelas correntes marxistas. Tal procedimento, além de servir de alerta para a transitoriedade dos significados atribuídos às palavras, nos permite atribuir um novo sentido às relações de poder. Anteriormente consideradas, sob a ótica marxista, como algo pernicioso e ruim, é agora, na visão do letramento crítico, entendida como algo que pode gerar frutos positivos. Diferentes visões de mundo, bem como os possíveis conflitos gerados por elas, são bem vindos na 
perspectiva do letramento crítico, na medida em que proporcionam aos sujeitos a oportunidade de poder examinar seus pressupostos bem como suas possíveis implicações.

A escola, nessa perspectiva apresentada por Jordão, tem um papel crítico, pois cabe a ela conscientizar o aluno das diferentes maneiras de construir sentidos existentes no mundo atual, mostrando-lhe, ao mesmo tempo, o potencial construtivo e destrutivo que pode resultar dos confrontos entre diferentes visões de mundo.

Jordão imprimiu atualidade no seu artigo quando discute o tema da transculturalidade virtual e seu efeito na construção de sentidos. Segunda ela, não há como negar que estamos cada vez mais inseridos num e influenciados por um mundo digital e virtual que está alterando não somente a maneira como nos vemos, mas, também, a maneira de nos relacionarmos e compreendermos o outro. Barreiras geográficas e físicas estão sendo derrubadas, dificultando a identificação de culturas e grupos culturais.

Por último, mas não menos importante, Jordão faz um entrelaçamento entre as línguas estrangeiras e transculturalidade quando discute a noção de cidadania em quatro dimensões: a primeira, relacionada ao conceito de transculturalidade; a segunda, relacionada à noção de nações como comunidades culturalmente estabelecidas e que, na minha opinião, é muito relevante àqueles professores de língua estrangeira que ainda resistem à idéia de que vivemos numa sociedade que está se globalizando (para usar um termo da autora) e que, por essa razão, está se tornando, felizmente, cada vez menos tolerante com a idéia de que identidades são construídas e determinadas dentro de barreiras geopolíticas; a terceira, relacionada à noção de terceiro espaço e a quarta relacionada com a língua.

Ao relacionar a noção de cidadania com a língua como discurso, Jordão, assim como Canagarajah, atribui, de forma menos explícita, mas não menos eficaz e contundente, a importância do papel do professor de língua estrangeira na formação dos cidadãos, pois, nas palavras de Jordão, “É na língua que as pessoas se inserem nas relações políticas locais e mundiais, e é nela também que são promovidos nossos entendimentos dos outros e de nós mesmos $\{. .$.$\} É na língua \{. .$.$\} que encontramos e confrontamos o diferente\{...\}”.$

\section{Referências}

Canagarajah, (1999). On EFL Teachers, awareness, and agency. ELT Journal, v. 53, n.3. 
Revista X, volume 2, 2008

Jordão, C.M. (2007). As lentes do discurso: letramento e criticidade no mundo digital. Trabalhos em Lingüística Aplicada, v. 46, n. 1.

Rajagopalan, K. (1999).Reply to Canagarajah. ELT Journal , v.53, n. 3. 